\title{
Environmental and Ecological Risk Assessment of Heavy Metal in Dredged Sediments in Lagos, Nigeria: An index Approach Analyses
}

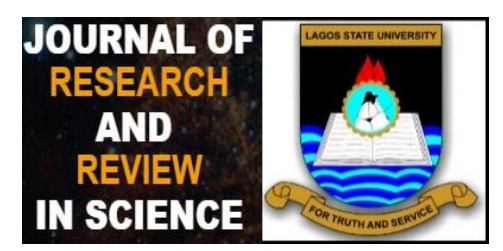

\author{
Abdulrafiu Majolagbe $^{1}$, Kafeelah Yusuf $^{2}$, Adebola Adeyi $^{3}$
}

1,2 Department of Chemistry, Faculty of Science,

Lagos State University, Nigeria

${ }^{2}$ Department of Neuroimaging Sciences, Center for Clinical Brain Sciences, University of Edinburgh, Edinburgh UK

${ }^{3}$ Department of Chemistry,

Faculty of Science,

University of Ibadan, Ibadan, Nigeria

\section{Correspondence}

Abdulrafiu Majolgbe,

Department of Chemistry,

Faculty of Science,

Lagos State University, Nigeria.

Email: abdulrafiu.majolagbe@lasu.edu.ng

\begin{abstract}
:
Introduction: Bio magnification and accumulation of trace heavy metals in the environment has been worrisome, causing gradual but high level of environmental degradation, particularly as a result of its non-degradable nature. Therefore, the need to monitor the trace metal loads in the environment.

Aims: The present study investigated the distribution of Heavy metals (Cadmium, Copper, Zinc, lead and Nickel) and potential ecological risk associated in surface sediments samples from six coastal communities (Ajah, Imore, Ilado, Ajindo, Ojo and Gbelejo) in Lagos, Nigeria

Materials and Methods: Composite samples were collected from ten (10) different locations in each of the communities and analysed of heavy metals using employing Atomic Absorption Spectrophotometer (AAS). The interim Sediment Quality Guidelines (ISQG) was applied to characterize the dredged sediments and assessment of the potential ecological risk on the environment through multivariate quality indices such as pollution index $(\mathrm{Pi})$, pollution classification (Pc), geo accumulation index (I geo) and potential ecological risk index (RI) was also carried.

Results: The concentration of zinc was observed higher in the sediments from commercially dredge areas (Ajah and Imore). The results obtained classified entire study area as polluted with respect of $\mathrm{Pb}$ and $\mathrm{Ni}$, and as contaminated with respect to other trace heavy metals $(\mathrm{Cd}, \mathrm{Cu}$, and $\mathrm{Zn})$ investigated. The ecological risk for the six study areas revealed moderate potential risk $(110 \leq \mathrm{RI}<200)$, except Imore and Gbelejo which showed low potential risk $(\mathrm{RI}<110)$.

Conclusion: Though the present levels of $\mathrm{Pb}$ and $\mathrm{Ni}$ in the study area is becoming noticeable, but the overall ecological risk for the entire study areas still fall within moderate potential risk. Hence, the need for regular monitoring by the relevant agencies to ensure safety of lives and sustainable environment.

Keywords: Ecological Risk Index, Dredged Sediment, Interim Sediment Quality Guidelines, Heavy Metals
\end{abstract}




\section{INTRODUCTION}

Lagos, Nigeria is a maritime hub [1]. The state is made up of over seventy five percent (75\%) coastal communities and serves as economic base for Nigeria, the most populous black nation in the world.

Estuarine in coastal areas have long been recognized as being of both ecological and economic importance [2]. Sediment in the estuarine area are constantly under the dynamic influence of multiple anthropogenic, or and naturally occurring stress induced factors originating from various sources such as agricultural, urban runoff, municipal sewage, industrial effluents and waste water and sometimes oil spillage $[3,4]$.

Dredging and excavation are the two common methods of removing sediments from a water body. Both methods involve moving sediment removed to a new transits location either for treatment, or and disposal. Sediment is regularly dredged by US Army Corps of Engineer thereby maintaining navigation channels for the purpose of recreation, national defence and commercial purposes [5]. Environmental dredging is also gaining momentum in developed countries, in which sediment is removed for the sole purpose of cleaning up the water body. Environmental dredging is intended to remove sediment contaminated above certain action levels, while minimizing the spread of contaminants to the surrounding environment during dredging [5].

Sutherland and Tolosa [4] reported the three factors that influence the magnitude and distribution of resuspended sediment in the near-field water column: (a) the physical properties of the sediments being dredged (quantified by grain size and distribution and specific gravity relative to the overlying waters); (b) the condition of the in situ sediments as reflected by in situ bulk density, void ratio, and other similar physical measurements; and (c) the physicochemical characteristics of the sediment or the overlying waters (e.g., salinity), which might affect the cohesiveness and consequently the flocculation and settling of sediment particles.

Dredging of sediment is now very rampant in Lagos, especially in the coastal area either for ecological and economic purposes. The dredging operations include the locals who deal in surface sediment and not too deep-water body using canoe and locally fabricated tools (shovel, basket), as well as the commercial licensed dredging companies that explore bottom sediment from deep water bodies. The dredged materials are transported to a transit station, from where it is disposed.

Sediment is the sink of various contaminants in a water body, including organic chemical, heavy and trace metals [6]. Heavy metals contamination remains a major environmental problem, particularly due to its non- biodegradability, its toxicity, multiple sources in the environment and its accumulative tendency. Heavy metal distribution in the marine sediments is influenced by texture, clay-minerals, organic matter, oxides, oxyhydroxides of iron and manganese and calcium carbonate [7].

The sediments have capacity to hold and release the adsorbed metals when the chemical conditions change, particularly the $\mathrm{pH}$, thereby leading to secondary metal pollution [8]. Sediment therefore could be a potential source of trace and heavy metals that originate from natural and anthropogenic processes and could have an adverse effect on the drinking water quality and human health. Although, Spatial distribution of heavy metals and other pollutant in sediment have been reported [9], which vary with time and site, metals such as copper, lead, mercury, or zinc and organic compounds such as pesticides, PCBs, and PAHs are the major contaminant constituents [10]. The use of sediments quality guidelines (SQG) to evaluate the potential adverse effect of pollutants in the sediment in the environment, among other things are well documented [11, 12].

This study was therefore designed to (i) determine the level of trace and heavy metals in dredged sediments in various part of coastal area of Lags state. (ii) apply Sediment Quality Guidelines (SQG) to characterize the dredged sediments and (iii) conduct the ecological risk assessment on the environment. The data generated will obviously aid the environmental managers and relevant agency in ensuring sustainability of the coastal areas of the state.

\section{MATERIAL AND METHODS \\ 2.1 Study area}

Six coastal communities from five different Local Government Area Councils in Lagos states formed the study area. These communities are densely populated with fishing, dredging and water transportation as their major preoccupations. There are no serious industrial activities in these communities, so they are largely free from direct exposure to industrial effluent except probably the Gbelejo coastal community which bound (about 20km) eastern side of Apapa, an industrial hub. The detail of the study area is captured in Table 1.0.and Figure 1.0.

\subsection{Samples and Sampling Technique}

Ten (10) different composite samples were collected from dredged sediments in the study area: Ajah (AJH), Imore (IMR), Ojo (OJO), Ilado (ILD), Ajindo (AJD) and Gbelejo (GJO). Composite sediment samples were collected with the aid of improved core sampler stored in a transparent polythene bag, marked and transported to laboratory for further analyses. 


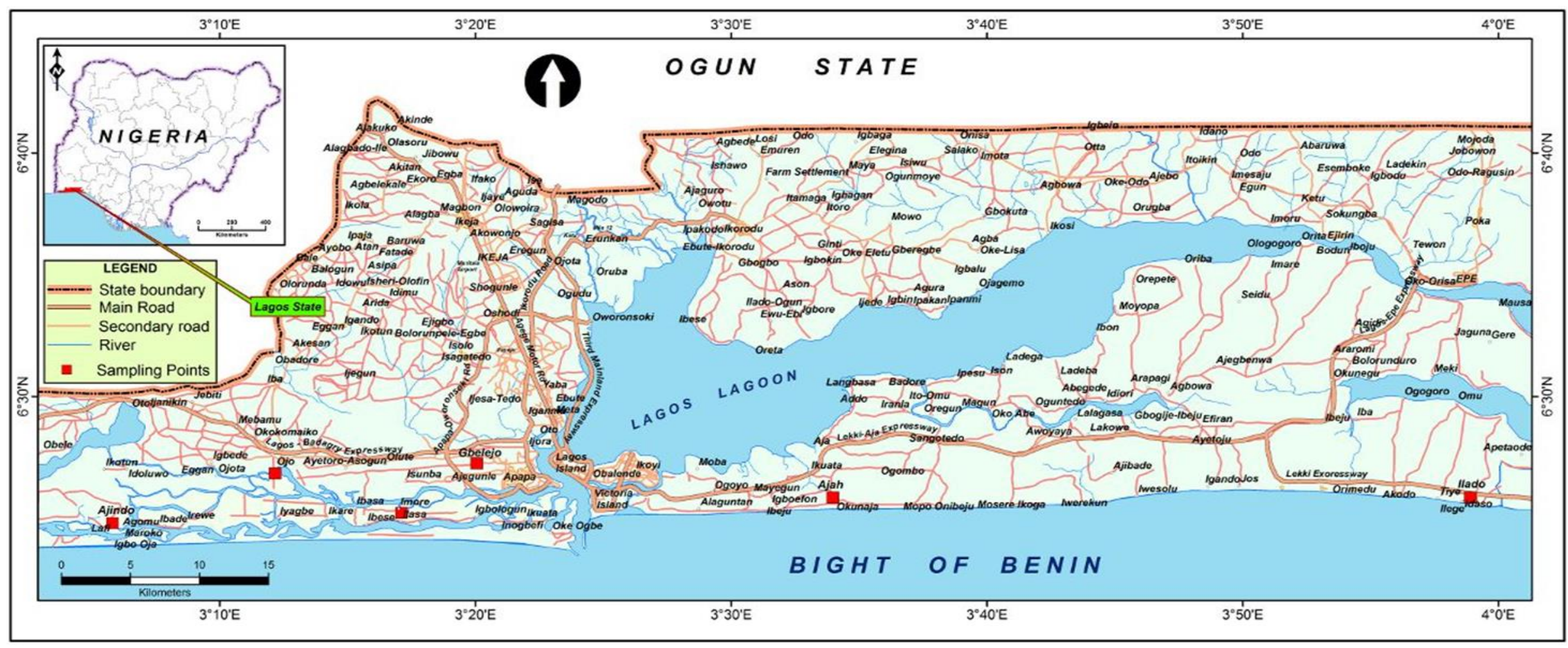

Fig. 1. Lagos State map showing the sampling locations 
The stainless auger was cleaned thoroughly in between sampling to avoid possible cross contamination.

\begin{tabular}{|c|c|c|c|c|}
\hline $\begin{array}{l}\mathbf{S} \\
\text { l } \\
\mathbf{N}\end{array}$ & $\begin{array}{l}\text { Study } \\
\text { Area }\end{array}$ & $\begin{array}{l}\text { Local } \\
\text { Govt. } \\
\text { Area }\end{array}$ & GPS & $\begin{array}{l}\text { Types of } \\
\text { dredging } \\
\text { activities }\end{array}$ \\
\hline 1 & Ajah & Lekki & $\begin{array}{l}6^{0} 25^{\prime} 511^{\prime \prime N} \\
3^{0} 33^{\prime} 8 " \mathrm{E}\end{array}$ & Commercial \\
\hline 2 & Imore & $\begin{array}{l}\text { Amuwo } \\
\text { odofin }\end{array}$ & $\begin{array}{l}6^{0} 25^{\prime} \quad 13^{\prime \prime} \mathrm{N} ; \\
3^{0} 17^{\prime}, 06 . " \mathrm{E}\end{array}$ & Commercial \\
\hline 3 & Ojo & Ojo & $\begin{array}{ll}6^{0} & 25 ' 51^{\prime \prime} \\
3^{0} 33^{\prime} 56^{\prime \prime} & \mathrm{N}\end{array}$ & Local \\
\hline 4 & Ilado & Badagry & $\begin{array}{ll}6^{0} & 255^{\prime} 51^{\prime \prime} \\
3^{0} 58^{\prime} 54^{\prime \prime} & \mathrm{N}\end{array}$ & Local \\
\hline 5 & Ajindo & Badagry & $\begin{array}{l}6^{0} 24^{\prime} \quad 48^{\prime \prime} \mathrm{N} ; \\
3^{0} 05^{\prime} 48^{\prime \prime} \mathrm{E}\end{array}$ & Local \\
\hline 6 & Gbelejo & Apapa & $\begin{array}{l}6^{0} 27^{\prime} 15^{\prime \prime} \mathrm{N} ; \\
3^{0} 20^{\prime} 03^{\prime \prime} \mathrm{E}\end{array}$ & Local \\
\hline
\end{tabular}

\subsection{Sample Pretreatment and Analyses}

The samples were air dried and pulverized into a uniform size using laboratory mill which was ensured clean in between each sample as a quality assurance measure. The pulverized sample were made to pass 2 $\mathrm{mm}$ mesh sieve and stored in acid washed dried polythene bottles with plastic screw cap prior to the analysis.

\subsubsection{Determination of $\mathrm{pH}$}

$10.0 \mathrm{~g}$ of the sieved sediment samples was weighed into a $250 \mathrm{ml}$ beaker and $10 \mathrm{ml}$ of distilled water was added. The mixture was vigorously shaken and allowed to stand for 1 hour. A blot dried $\mathrm{pH}$ meter (Mettler Toledo IP67 model) that has been pre-calibrated with buffer solutions of 4, 7 and 9, was dipped into the mixture and $\mathrm{pH}$ value was taken $[13,14]$.

\subsubsection{Heavy Metal Analysis in Sediment Samples}

A mixture of $36 \mathrm{ml} \mathrm{HNO} 3,12 \mathrm{ml} 50 \% \mathrm{HF}$ and $2 \mathrm{ml} \mathrm{HCl}$ (Analar grade) was added into $250 \mathrm{ml}$ round bottom flask containing $10.0 \mathrm{~g}$ sediment sample. It was refluxed for 2 hours until no brown fumes were given off by the sample [2]. The sample was washed, rinsed with double distilled water, filtered using Whatman No. 1 filter paper and the filtrate made up in $100 \mathrm{ml}$ standard volumetric flask. Heavy metal determination was done with Atomic Absorption Spectrometer (Pye Unicam Philips Model $900 \mathrm{X})$.

Calibration curve was prepared with standard solution of pure metals of concentration ranging from $0.0-40.0$ $\mathrm{mg} / \mathrm{L}$ at $5.0 \mathrm{mg} / \mathrm{L}$ increment. Duplicate determinations were carried out for each of the samples to test for the reproducibility of the method. Blank sample was also analysed to correct any variation that may result from purity of the reagents used for digestion.

\subsection{Data Analyses}

Descriptive analyses of data generated were carried out using Graph Pad Prism (version 5.00). Correlation coefficient was performed in a pair wise fashion employing Pearson correlation coefficient. The data were subjected to various multivariate indices which include pollution index $(\mathrm{Pi})$ and pollution classification $(\mathrm{Pc})$. The data were also used in determining the Geoaccumulation Index and Potential Ecological Risk Index of the metals in the environment.

\subsubsection{Pollution Index $\left(P_{i}\right)$}

Pollution index is a degree of soil pollution of soil with reference to a specific metal, and it has been used to assess urban soil pollution. Liu et al., [15] obtained ${\underline{\mathbf{P}_{i}}}_{\mathbf{i}}$ as a ratio of metal concentration in a contaminated soil sample and its concentration in control sample. However, Diatta et al., [16] obtained $\underline{\mathbf{P}}_{\mathbf{i}}$ as a ratio of the metal concentration in a contaminated soil sample and the local Maximum Allowable Limit (MAL) values of the metal. Values considered as MAL of heavy metals vary from place to place and depend on local background values [17]. Pollution index had also been calculated as ratio of metal concentration in sample to background concentration [18].

Where:

$$
\mathrm{P}_{\mathrm{i}}=\quad \mathrm{C}_{\mathrm{n}}^{\mathrm{i}} / \mathrm{C}^{\mathrm{i}}{ }_{\mathrm{b}}
$$

$\mathrm{C}^{i}$ is the concentration of the ith soil pollutant, and $\mathrm{C}^{i}{ }_{b}$ is the relative metal concentration of pollutant in control sample or background value in $\mathrm{mgkg}-1$.

\subsubsection{Pollution Classification $\left(\mathbf{P}_{\mathrm{c}}\right)$}

This helps to establish the distinction between soil contamination and soil pollution range. $P_{c}$ Values above 1.0 depicts the pollution range, while those below 1.0 indicate the contamination range. Pollution index obtained can be used to compute $\underline{\mathbf{P}}_{\mathbf{c}}$ of an area using the formula of the Dutch system [18, 19]. Pollution classification $\left(\mathbf{P}_{\mathbf{c}}\right)$ was calculated as reported by Chee et al., [19]:

$$
P c=\frac{C_{n}^{i}-C_{b}^{i}}{P_{i}}
$$

Where:

$\mathrm{C}_{\mathrm{n}}{ }_{\mathrm{n}}$ is the concentration of the ith soil pollutant, and $\mathrm{C}^{\mathrm{i}}{ }_{\mathrm{b}}$ is the relative metal concentration of pollutant in control sample or background value in mgkg-1 and $\mathrm{Pi}$ is pollution index

\subsubsection{Geo accumulation Index (Igeo)}

The Igeo of heavy metals in the sediment helps in determining the extent of heavy metal accumulation in sediments, and it has been reported by various studies $[20,21,14]$. Igeo can be calculated through the mathematical relationship,

$$
\mathrm{I}_{\text {geo }}=\log 2 \frac{\left[\mathrm{C}_{\text {metal }} \text { sample }\right]}{1.5\left[\mathrm{C}^{\mathrm{i}} \mathrm{b}\right]}
$$

Where, $\mathrm{C}_{\text {metal }}$ sample, is the concentration of the heavy metal in the sediment samples. $\mathrm{C}_{\mathrm{b}}^{\mathrm{i}}$ is the geochemical background value or control sample value. The factor 1.5 is incorporated in the relationship to account for possible variations in the background or control which 
may be attributed to lithogenic variations in the soil [22]. The degree of metal pollution is assessed in terms of seven contaminant categories based on increasing value of the index as follow: Igeo $=0$ means unpolluted; $0<=$ I geo $_{1}<1$ means unpolluted to moderately polluted; $1<=$ Igeo $<2$ means moderately polluted; $2<=$ Igeo $_{\text {g }}<3$ means moderately to strongly polluted; $3<=$ Igeo $<4$ means strongly polluted; $4<=I_{\text {geo }}<5$ means strongly to very strongly polluted and $I_{g e o}>=5$ means very strongly polluted.

\subsubsection{Potential Ecological Risk Index (RI)}

The Potential Ecological Risk Index (RI) was originally introduced by Hakanson [23]to assess the degree of heavy metal pollution in soil, according to the toxicity of metals and the response of the environment. RI could evaluate ecological risk caused by toxic metals comprehensively. The calculating methods of $\mathrm{Rl}$ are listed below:

$$
\begin{aligned}
& \mathrm{Fi}=\mathrm{C}^{\mathrm{i}} \mathrm{n} / \mathrm{C}^{\mathrm{i} o} \\
& \mathrm{E}_{\mathrm{r}}^{\mathrm{i}}=\mathrm{Ti}^{\mathrm{i}} \times \mathrm{F}_{\mathrm{i}} \\
& \mathrm{RI}=\Sigma n i=1 E
\end{aligned}
$$

where $\mathrm{F}_{\mathrm{i}}$ is the single metal pollution index; $\mathrm{C}^{\mathrm{i}} \mathrm{n}$ is the concentration of metal in the samples; Cio is the reference value for the metal; $E^{i}{ }_{r}$ is the monomial potential ecological risk factor; Tir is the metal toxic response factor according to [23]. The values for each element are in the order $\mathrm{Zn}=1<\mathrm{Cr}=2<\mathrm{Cu}=\mathrm{Ni}=\mathrm{Pb}$ $=5<\mathrm{As}=10<\mathrm{Cd}=30$. $\mathrm{Rl}$ is the potential ecological risk caused by the overall contamination. There are four categories of RI and five categories of Eir as shown in Table 2.0.

Table 2. Grades of single and overall Ecological Potential Risks

\begin{tabular}{llll}
\hline$E_{r}^{i}$ value & Grades of ecological risk of metals & RI value & Grades of the environment \\
\hline$E_{r}^{i}<\mathbf{4 0}$ & Low ecological potential risk & $R I<110$ & Low ecological potential risk \\
$\mathbf{4 0} \leq \mathrm{E}_{r}^{i}<\mathbf{8 0}$ & Moderate ecological potential risk & $110 \leq \mathrm{RI}<200$ & Moderate ecological potential risk \\
$\mathbf{8 0} \leq \mathrm{E}_{\mathrm{r}}^{\mathrm{i}}<\mathbf{1 6 0}$ & Considerable ecological potential risk & $200 \leq \mathrm{RI}<400$ & strong ecological potential risk \\
$\mathbf{1 6 0} \leq \mathrm{E}_{\mathrm{r}}^{\mathrm{i}}<\mathbf{3 2 0}$ & High ecological potential risk & $400 \leq \mathrm{RI}$ & Very strong ecological potential risk
\end{tabular}

$320 \leq E^{i}{ }_{r} \quad$ Significant very ecological potential risk

\section{RESULTS AND DISCUSSION}

The descriptive statistics of $\mathrm{pH}$ and heavy metals concentration in dredge sediments collected from study areas is presented in Table 3.0, while Figures 2.0 and 3.0 show the bar chats presentation of metals in commercial and local dredging areas respectively.

The $\mathrm{pH}$ is an important parameter that affect the mobility of metals in the aquatic environment.

The $\mathrm{pH}$ values observed for sediment samples analysed ranged between $7.4-8.2,7.6-8.2,7.6-8.1$, 7.2 - 7.5, 7.6 - 8.0 and 7.7 -8.2 for Ajah, Imore, Ojo, Ilado, Ajindo and Gbelejo areas respectively.

The $\mathrm{pH}$ values observed was in alkaline region irrespective of the type of dredging (commercial or local). The $\mathrm{pH}$ appeared a function of mineralogy makeup of the ocean bed. A number of studies have reported variation of $\mathrm{pH}$ values in sediment [24,25].

The concentration of metals investigated in this study was compared to Canadian Council of Ministers of the Environment Guidelines for the Protection of Aquatic Life (CCME). CCME derives two guidelines; the lowest effect level, (LEL) or threshold effect level (TEL) of interim sediment quality guidelines (ISQG), which represent concentration of contaminants below which there is a very low probability of effects on the biota and the severe effect levels (SEL) or probable effect level (PEL) which represent concentrations above which there is a high ( $>50 \%$ ) probability of adverse effect on the biota.

Heavy metals distribution in the marine sediments is influenced by texture, clay-minerals, organic matter, oxides, oxyhydroxides of iron and manganese and calcium carbonate in the sediment [7].

Zinc and copper are essential metals but becomes toxic when present in excessive concentration. Zinc level in this study was higher in commercial dredging areas (Ajah and Imore) compared to local dredging areas.

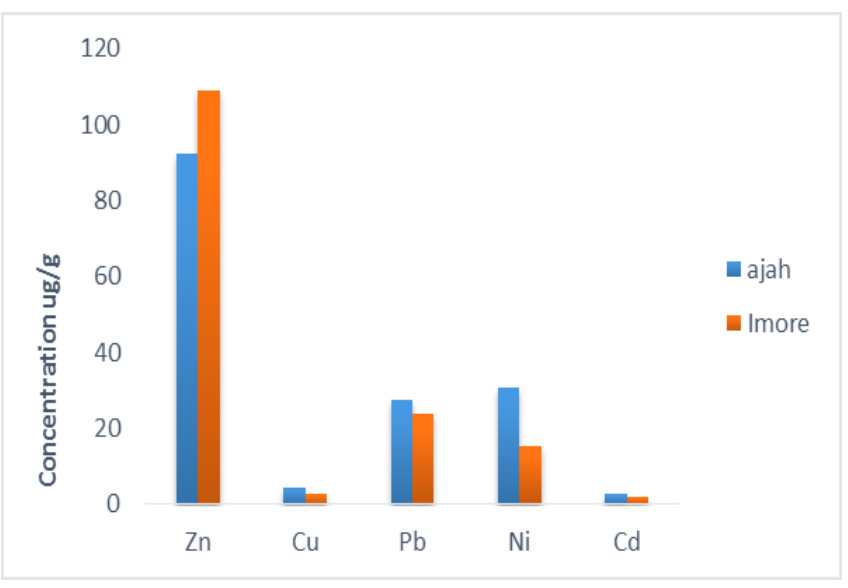

Fig. 2. Bar chart representation of commercially dredge sediment from Ajah and Imore areas 
Table 3. Descriptive statistics of $\mathrm{pH}$ and heavy metals $(\mu \mathrm{g} / \mathrm{g})$ in sediment in coastal communities in Lagos

\begin{tabular}{|c|c|c|c|c|c|c|c|c|c|c|c|c|c|c|c|c|c|c|}
\hline \multirow[t]{2}{*}{ Site } & \multicolumn{3}{|c|}{$\mathrm{pH}$} & \multicolumn{3}{|c|}{$\mathrm{Zn}$} & \multicolumn{3}{|c|}{$\mathrm{Cu}$} & \multicolumn{3}{|c|}{$\mathrm{Pb}$} & \multicolumn{3}{|c|}{$\mathrm{Ni}$} & \multicolumn{3}{|c|}{ Cd } \\
\hline & Mean \pm SD & SEM & $\mathrm{CV}$ & Mean $\pm S D$ & SEM & $\mathrm{CV}$ & Mean \pm SD & SEM & $\mathrm{CV}$ & Mean \pm SD & SEM & CV & Mean \pm SD & SEM & $\mathrm{CV}$ & Mean \pm SD & SEM & $\mathrm{CV}$ \\
\hline Ajah & $7.74 a \pm 0.1$ & 0.03 & 1.4 & $92.3 a \pm 34$ & 11 & 38 & $4.24 \mathrm{a} \pm 2.5$ & 0.8 & 58 & $27.4 a \pm 2.9$ & 0.9 & 10 & $30.6 a \pm 1.8$ & 0.6 & 60 & $2.87 a \pm 0.2$ & 0.1 & 8.0 \\
\hline Imore & $7.94 b \pm 0.1$ & 0.01 & 0.7 & $109 a \pm 30$ & 9.7 & 27 & $2.58 a \pm 0.5$ & 0.5 & 0.2 & $23.8 b \pm 2.1$ & 0.7 & 8.8 & $15.5 b \pm 1.4$ & 0.5 & 9.2 & $1.89 b \pm 0.3$ & 0.1 & 17 \\
\hline Ojo & $7.93 b \pm 0.08$ & 0.03 & 1.0 & $35.4 b \pm 2.3$ & 1.03 & 6.5 & $3.6 b \pm 0.34$ & 0.15 & 9.4 & $43.0 c \pm 7.2$ & 3.2 & 17 & $31.9 a \pm 2.9$ & 1.3 & 9.1 & $2.62 a \pm 0.3$ & 0.03 & 1.0 \\
\hline llado & $7.35 c \pm 0.1$ & 0.08 & 1.5 & $39.5 c \pm 0.2$ & 0.15 & 0.4 & $5.05 c \pm 0.6$ & 0.4 & 11 & $32.3 d \pm 11$ & 7.9 & 35 & $41.5 c \pm 0.4$ & 0.25 & 0.8 & $4.13 c \pm 0.7$ & 0.36 & 12 \\
\hline Ajindo & $7.81 \mathrm{~d} \pm 0.1$ & 0.1 & 1.8 & $36.5 d \pm 1.4$ & 0.8 & 3.8 & $4.8 d \pm 0.3$ & 0.23 & 6.6 & $24.0 b \pm 1.5$ & 1.1 & 6.1 & $24.3 d \pm 2.5$ & 1.8 & 10 & $3.45 c \pm 0.6$ & 0.45 & 18 \\
\hline Gbelejo & $7.82 \mathrm{~d} \pm 0.06$ & 0.07 & 1.1 & $35.4 d \pm 3.1$ & 3.1 & 5.3 & $4.2 a \pm 0.7$ & 0.4 & 10 & $23.3 b \pm 6.2$ & 0.8 & 11 & $28.5 a \pm 2.2$ & 0.7 & 13 & $4.8 c \pm 0.3$ & 0.5 & 11 \\
\hline BV & & & & 175.3 & & & 11.0 & & & 11.6 & & & 4.7 & & & 1.2 & & \\
\hline CCME & & & & 120 & & & 16 & & & 31 & & & 16 & & & 0.6 & & \\
\hline \multicolumn{19}{|l|}{ TEL } \\
\hline PEL & & & & 820 & & & 110 & & & 250 & & & 75 & & & 10 & & \\
\hline
\end{tabular}

BV - Background value same alphabet in each column indicates no significant difference

The possible sources of zinc in aquatic environment include industrial effluent discharges, run-off from agricultural fields, mineralogy of sea beds and the use of zinc nodules in ship building and repair. Zinc nodules are important materials employed in cathodic protection and coats painting of ships [12]. The concentrations of zinc observed in this study were below the limits of TEL and PEL values.

The order of levels of zinc across the study areas is Imore $>$ Ajah $>$ Ilado $>$ Ajindo $>$ Gbelejo > Ojo. They bio accumulate, bio magnify in the living tissues and are known to be non-degrading. Toxic metals generally interfere with functioning of metabolic reactions in living cells, thereby responsible for a number of disease condition $[26,27,28]$ The mean concentration of $\mathrm{Pb}$ was found higher than the TEL value of $31.0 \mathrm{mg} / \mathrm{Kg}$ in both Ojo and llado areas only, while the nickel and cadmium concentrations observed was higher than the TEL value of 16 and $0.6 \mathrm{mg} / \mathrm{Kg}$ respectively in all the study areas but lower than the PEL limits. This suggests the need for regular monitoring because of the effect of bioaccumulation and magnification of metals in the environment.
The pollution index, pollution classification and geo accumulation index in the sediments analysed are shown in Table 4.0. The trend of variation of pollution index across the study areas are as follow; $\mathrm{Cu}<\mathrm{Zn}<\mathrm{Pb}<\mathrm{Cd}<\mathrm{Ni}$ for Ajah; $\mathrm{Cu}<\mathrm{Zn}<$ $\mathrm{Cd}<\mathrm{Pb}<\mathrm{Ni}$ for Imore; $\mathrm{Zn}<\mathrm{Cu}<\mathrm{Cd}<\mathrm{Pb}<\mathrm{Ni}$ for Ojo and $\mathrm{Zn}<\mathrm{Cu}<\mathrm{Pb}<\mathrm{Cd}<$ Ni for Ilado, Ajindo and Gbelejo.

while the order of copper level across the study areas follow llado > Ajindo > Ajah $>$ gbelejo > Ojo > Imore.

The level of $\mathrm{Cu}$ observed in this study was below the limits of TEL and PEL of Canadian Council of Ministers of the Environment Guidelines for the Protection of Aquatic Life. Copper is essential for metabolic processes in living system. Lead, Nickel and Cadmium are toxic metals, even at low concentration. These toxic elements occur naturally in the environment and can be an end product of anthropogenic activities. 


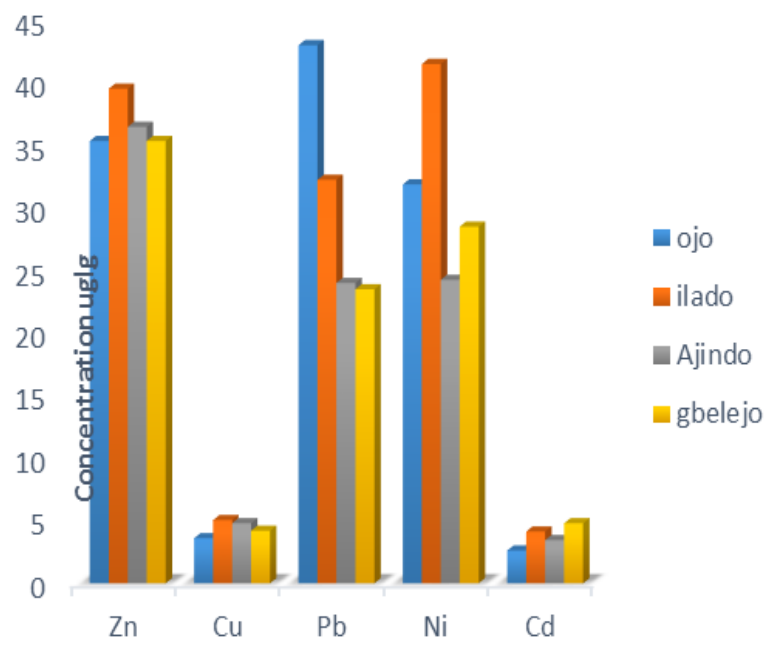

Fig. 3. Bar chart representation of locally dredge sediment from Ojo, llado, Ajindo and Gbelejo areas

They bio accumulate, bio magnify in the living tissues and are known to be non-degrading. Toxic metals generally interfere with functioning of metabolic reactions in living cells, thereby responsible for a number of disease condition [26, 27, 28] The mean concentration of $\mathrm{Pb}$ was found higher than the TEL value of $31.0 \mathrm{mg} / \mathrm{Kg}$ in both Ojo and Ilado areas only, while the nickel and cadmium concentrations observed was higher than the TEL value of 16 and $0.6 \mathrm{mg} / \mathrm{Kg}$ respectively in all the study areas but lower than the PEL limits.

This suggests the need for regular monitoring because of the effect of bioaccumulation and magnification of metals in the environment. The pollution index, pollution classification and geo accumulation index in the sediments analysed are shown in Table 4.0.The trend of variation of pollution index across the study areas are as follow; $\mathrm{Cu}<\mathrm{Zn}<\mathrm{Pb}<\mathrm{Cd}<\mathrm{Ni}$ for Ajah; $\mathrm{Cu}<\mathrm{Zn}<$ $\mathrm{Cd}<\mathrm{Pb}<\mathrm{Ni}$ for Imore; $\mathrm{Zn}<\mathrm{Cu}<\mathrm{Cd}<\mathrm{Pb}<\mathrm{Ni}$ for Ojo and $\mathrm{Zn}<\mathrm{Cu}<\mathrm{Pb}<\mathrm{Cd}<\mathrm{Ni}$ for llado, Ajindo and Gbelejo.

The entire study sites can be classified polluted in respect of $\mathrm{Pd}$ and $\mathrm{Ni}$ while in respect of other metals, the study areas can be classified as contaminated.

Table 4. Pollution Index and Pollution Classification and Geo Accumulation Index in sediment in coastal communities in Lagos

\begin{tabular}{|c|c|c|c|c|c|c|c|c|c|c|c|c|c|c|c|}
\hline Site & & $\mathrm{Zn}$ & & & $\mathrm{Cu}$ & & & $\mathrm{Pb}$ & & & $\mathrm{Ni}$ & & & $\mathrm{Cd}$ & \\
\hline & $\mathbf{P}_{\mathbf{i}}$ & $\mathbf{P}_{\mathrm{c}}$ & $I_{\text {geo }}$ & $\mathbf{P}_{\mathbf{i}}$ & $\mathbf{P}_{\mathbf{c}}$ & $I_{\text {geo }}$ & $\mathbf{P}_{\mathbf{i}}$ & $\mathbf{P}_{\mathrm{c}}$ & $I_{\text {geo }}$ & $\mathbf{P}_{\mathbf{i}}$ & $\mathbf{P}_{\mathrm{c}}$ & $I_{\text {geo }}$ & $\mathbf{P}_{\mathbf{i}}$ & $\mathbf{P}_{\mathrm{c}}$ & $I_{\text {geo }}$ \\
\hline Ajah & 0.53 & -156 & -1.5 & 0.34 & -19.9 & -1.9 & 2.36 & 6.70 & 0.68 & 6.51 & 3.98 & 2.11 & 2.39 & 0.70 & 0.67 \\
\hline Imore & 0.62 & -106 & -1.2 & 0.23 & -36.5 & -2.4 & 2.05 & 5.95 & 0.49 & 3.30 & 3.27 & 1.14 & 1.58 & 0.43 & 0.07 \\
\hline Ojo & 0.20 & -635 & -2.9 & 0.23 & -32.1 & -2.1 & 3.71 & 8.46 & 1.32 & 6.78 & 4.1 & 2.81 & 2.18 & 0.65 & 0.54 \\
\hline Ilado & 0.22 & -617 & -2.7 & 0.32 & -18.6 & -1.7 & 2.78 & 7.45 & 0.89 & 8.83 & 4.17 & 2.59 & 3.41 & 0.86 & 1.19 \\
\hline Ajindo & 0.21 & -660 & -2.9 & 0.43 & -14.4 & -1.7 & 2.07 & 6.00 & 0.49 & 5.17 & 3.79 & 1.79 & 2.88 & 0.78 & 0.93 \\
\hline Gbelejo & 0.20 & -699 & -2.7 & 0.38 & -17.9 & -2.0 & 2.00 & 5.85 & 0.41 & 6.06 & 3.93 & 2.01 & 4.00 & 0.9 & 1.42 \\
\hline
\end{tabular}

This reflects a very high level of $\mathrm{Pb}$ and Nickel in the areas investigated. Sources of nickel and lead in aquatic environment include urban run - off, industrial discharges and run off from agricultural fields as well as geological formation of an area. Leaching of metals from the surface coat of the ship and boat is another source of metals just as the oil waste and oil spill can also contribute greatly to the amount of $\mathrm{Pb}$ in the water body and sediments. These two metals ( $\mathrm{Pb}$ and $\mathrm{Ni}$ ) have been implicated in a number of diseases conditions, hence the need to continuously monitor the water environment.

The geo accumulation index (Igeo) reveal variations of pollution status in the study area with regards to the metals determined. The study areas varied from moderately polluted to strongly polluted in respect of nickel but only moderately polluted in respect of $\mathrm{Pb}$. llado and Gbelejo areas showed moderate pollution in respect of $\mathrm{Cd}$ while others coastal areas investigated showed unpolluted status. The ecological potential risks of heavy metals in the sediment from the six study areas are presented in Table 5.0.
Table 5. Heavy Metal Ecological Potential Risk Indices in sediment in coastal communities, Lagos

Site Monomial Ecological Risk For

\begin{tabular}{lllllll} 
& \multicolumn{6}{l}{ Metals } \\
\cline { 2 - 7 } Ajah & $\mathrm{Zn}$ & $\mathrm{Cu}$ & $\mathrm{Pb}$ & $\mathrm{Ni}$ & $\mathrm{Cd}$ & $\mathrm{RI}$ \\
Imore & 0.62 & 1.70 & 11.2 & 32.6 & 71.7 & 117.7 \\
Ojo & 0.20 & 1.15 & 18.6 & 33.9 & 65.4 & 119.3 \\
Ilado & 0.22 & 1.60 & 13.9 & 44.2 & 102.2 & 162.1 \\
Ajindo & 0.21 & 2.15 & 10.4 & 25.9 & 86.4 & 125.1 \\
Gbelejo & 0.20 & 1.90 & 10.0 & 30.3 & 42.6 & 85.0 \\
\hline
\end{tabular}

The average monomial ecological potential risk for zinc, copper, lead and nickel in all the study areas posed low potential risk $(<40)$ except nickel in llado which reveal a moderate ecological potential risk. However, the trend observed in the cadmium showed a potential ranging from moderate to considerable ecological potential risk. 
The overall ecological risk for the six study areas revealed moderate potential risk, except Imore and Gbelejo which showed low potential risk (<110).

\section{CONCLUSION}

The level of heavy metals in the dredge sediments from six coastal communities in Lagos and their associated ecological risk was investigated. The level of lead, nickel and cadmium observed in this study was higher than their respective background values indicating that the magnitude of these toxic elements in the study area is a cause of health concern. The entire study sites can be classified polluted in respect of $\mathrm{Pd}$ and $\mathrm{Ni}$ (Igeo >1) while in respect of other metals, the study areas can be classified as contaminated. The overall ecological risk for the six study areas revealed moderate potential risk $(110 \leq \mathrm{RI}<200)$, except Imore and Gbelejo which showed low potential risk $(R I<110)$. Measures must be set up the stakeholders in environmental management to prevent cross contamination of environment in the course of transferring the sediment to the initial transits stations, thereby ensuring sustainability.

\section{REFERENCES}

1. Lagos indicator. Ongoing transformation in Lagos: a rare blend of continuity, competence, cooperation and vision. Lagos indicator, 2009; 2(1): 11-12.

2. USEPA. Liquid assets 2000: America's water resources at a turning point. EPA 840-B-00-001. 2000, Office of Water, Washington.

3. Viers J, Dupréa B, Gaillardet J. Chemical composition of suspended sediments in World Rivers: new insights from a new database. Sci. Total Environ. 2009; 407: 853-868.

4. Sutherland RA, Tolosa CA. "Multi-element analysis of road-deposited sediment in an urban drainage basin, Honolulu, Hawaii," Environmental Pollution, 2000; 110(3):483-495.

5. NRC (National Research Council). Urban storm water management in United States. Washington D.C. $2008 ; 18-20$.

6. Malferrari D, Brigatti MF, Laurora A, Pini S. Heavy metals in sediments from canals for water supplying and drainage: mobilization and control strategies J. Hazard Matter. 2009; 161: 723-9.

7. Claudia GV, Batista DS, Batista NJA. Benthic foraminifera distribution in high polluted sediments from Niterói Harbor (Guanabara Bay), Rio de Janeiro, Brazil An. Acad. Bras. Ciênc. 2004; 76 :1-10.

8. Segura $R$, Arancibia $V$, Zúñiga $M C$, Pastén $P$. Distribution of copper, zinc, lead and cadmium concentrations in stream sediments from the Mapocho River in Santiago, Chile Journal of Geochemical Exploration, 2006; 91: 71-80.

9. Balkis N, Aksu A, Okus E, Apak R. Heavy metals concentration in water, suspended matters and sediments from Gokova Bay, Turkey. Environmental monitoring and assessment, 2010; (1-4):359-70. 10. Long ER. Degraded sediment quality in US estuaries: a review of magnitude and ecological implications. Ecol. Appl., 2002; 10:338-349.
11. Sarva MP, Miroslav R, MohdHarun A, Ahmed ZA. Application of sediment quality guideline in the assessment of mangrove surface sediment in Mengkabong, Lagoon Sabah. Global Journal of Environmental Research, 2003,1, p. 1-9.

12. Majolagbe $A O$, Osibanjo O, Yusuf KA, Olowu RA. Trace Metals Distribution and Contamination in the Surface Marine Sediments of Roro Bay in Lagos, Nigeria. Chemistry Journal, 2012; 2: 69-78.

13. SERAS (Scientific Engineering Response Analytical services). Standard Operating Procedures. 2002, Soil test No. 1844, Washington, p. 32.

14. Majolagbe AO, Alkali II, Onwordi CT. Ecological Risk Assessment of Soil Metallic Pollution in Mechanic Villages, Abeokuta, Nigeria. Journal of Environment. 2014; 3: 1- 9.

15. Liu C, Zhang Y, Zhang F, Zhang S, Yin M, Ye H, Hou $\mathrm{H}$, Dong $\mathrm{H}$, Zhang $M$, Jiang J, Pei L. Assessing pollutions of soil and plant by municipal waste dump. Environ. Geol., 2007; 52: 205-207.

16. Diatta JB, Kociałkowski WZ, Grzebisz W. Lead and zinc partition coefficients of selected soils. Comm. Soil Sci. Plant Anal., 2003; 34: 17-18.

17. Kloke A. Richwerte, Orientierungsdaten für tolerierbare Gesamtgehalte einiger Elemente in Kulturböden, zitt. VDLUFA, H, (1980) 2: 9-11.

18. Lacatusu R. Appraising levels of soil contamination and pollution with heavy metal. European Soil Bureau Joint Research Centre, 1998: 393-402.

19. Chee PS, Tahir NM, Zuchi HM, Musa MI, HorkNg K, Noor AM. Heavy metal content in soil of major towns in the east coast of peninsular Malaysia. Chinese J. Geoch., 2006; 25: 56-63.

20. Chakravarty M, Patgiri AD. Metal Pollution Assessment in Sediments of the Dikrong River, N.E. India. J Hum Ecol., 2009; 27: 63-67.

21. Lei Z, Qianjiahua L, Shiguang S, Nan Z., Qiushi S, Cheng L. Heavy Metal Pollution,

Fractionation, and Potential Ecological Risks in Sediments from Lake Chaohu (Eastern China) and the Surrounding Rivers. Int. J. Environ. Res. Public Health. 2015; 12: 14115-14131.

22. Mediolla LL., Domingues MCD, Sandova, MRG. Environmental Assessment of Active Tailings Pile in the State of Mexico (Central Mexico). Research Journal of Environental. Science, 2008; 2:197-208.

23. Hakanson LL. An ecological risk index aquatic pollution control, a sedimentological approach

Water Res., 1980; 14: 975-1001.

24. Hollister, E B.; Engledow, A. S.; Hammett, A.M,; Provin TL, Wilkinson HH, Gentry TJ,. Shifts in microbial community structure along an ecological gradient of hypersaline soils and sediments. ISME Journal, 2011; 4: 829-838.

25. Shuai L, Hongxing R, Lidong S, Liping L.. Ping Z, Baolan $\mathrm{H}$. pH levels drive bacterial community structure in sediments of the Qiantang River as determined by 454 pyrosequencing. Front Microbiol., 2015; 6: 285.

26. Velma V, Tchounwou, PB. Chromium-induced biochemical, genotoxic and histopathologic effects in liver and kidney of goldfish, carassius auratus. Mutat Res. 2010, 698(1-2), p. 43-51. 
27. Yedjou CG, Steverson M, Tchounwou PB. Lead nitrate-induced oxidative stress in human liver carcinoma (HepG2) cells. Metal lons Biol Med. 2006; 9: 293-297.
28. Yedjou CG, Milner J, Howard C, Tchounwou PB. Basic apoptotic mechanisms of lead toxicity in human leukemia (HL-60) cells. Intl J Environ Res Public Health, 2010;7: 2008-2017. 